24. Novak, L. P., Hamamoto, K., Orvis, A. L., and Burke, E. C.: Total body potassium in infants. Amer. J. Dis. Child., 119: 419 (1970).

25. Reba, R. C., Cheek, D. B., and Leitnaker, F. C.: Human growth. In: D. B. Cheek: Body Composition, Cell Growth, Energy and Intelligence, p. 165. (Lea \& Febiger, Philadelphia, 1968).

26. Remenchik, A. P., Miller, C. E., and Kessler, W. V.: Estimates of body composition derived from potassium measurements. United States Atomic Energy Commission, Argonne National Laboratory, 73: 231 (1968).

27. Snedecor, G. W., and Cochran, W. G.: Statistical Methods, Ed. 6, pp. 172, 381 (Iowa State University Press, Ames, Iowa, 1967).

28. Tyson, I., Genna, S., Jones, R. L., Bikerman, V., and Burrows, B. A.: Body potassium measurements with a total body counter. $J$. Nucl. Med., 11: 255 (1970).

29. Waterlow, J. C.: Classification and definition of protein-calorie malnutrition. Brit. Med. J., 3: 566 (1972).

30. Waterlow, J. C., and Alleyne, G. A. O. Protein malnutrition in children: Advances in knowledge in the last ten years. Advan. Protein Chem., 25: 117 (1971).
31. Wolfson, W. Q., Cohn, C., Calvary, E., and Ichaba, F.: Studies in serum proteins $V$. A rapid procedure for the estimation of total protein, true albumin, total globulin, alpha globulin, beta globulin and gamma globulin in $1.0 \mathrm{ml}$ of serum. Amer. J. Clin. Pathol., 18: 723 (1948).

32. Financial assistance was received from the Cape Provincial Administration, the South African Atomic Energy Board and National Institutes of Health Public Health Service Grant no. AMO-3995.

33. The investigations were approved by the Screening Committee of National Institutes of Health Public Health Service Grant no. AMO-3995. The nature of the procedure and the purpose of the study were explained to the mothers of the children and children were studied only after informed consent was obtained.

34. Requests for reprints should be addressed to: M. D. Bowie, M.D., Department of Paediatrics and Child Health, Medical School, University of Cape Town, Observatory, Cape, South Africa. 35. Accepted for publication July 5, 1974.
Amino acids anaerobiosis intestine

\title{
Metabolic Properties of Neonatal Transport
}

\author{
L. D. FERDINANDUS AND J. F. FITZGERALD(45) \\ Department of Pediatrics, Indiana University School of Medicine, Indianapolis, Indiana, USA
}

S. REISER

Carbohydrate Laboratory, Nutritional Institute, Department of Agriculture, Beltsville, Maryland, USA

\section{Extract}

The metabolic properties of the increased rate of transport in the 2-day-old rat intestine as compared with adult rat intestine were investigated. The intracellular accumulation of 1 $\mathrm{mM}$ of a prototype neutral amino acid (L-leucine) and sugar (D-galactose) was measured at $5 \mathrm{~min}$ in the presence of inhibitors and after preincubation with inhibitors. The intestine of the 2-day-old rat was found to be similar to adult rat intestine in its response to $\mathrm{Na}^{+}$dependence, sulfhydryl binders, and metabolic inhibitors under conditions of aerobiosis; however, the immature rat intestine exhibited an ability to actively accumulate amino acids to a much greater extent than adult tissue under anaerobic conditions. Transport was inhibited only $12 \%$ in the newborn intestine while adult intestine showed a $44 \%$ inhibition at initial velocities. This anaerobic transport was similarly $\mathrm{Na}^{+}$dependent and sensitive to metabolic inhibitors.

These results indicate that the increased transport found in newborn animals may be partially energized by anerobic metabolism, but suggest that the requirement for the maintenance of an active influx of sodium is similar in both neonates and adults.

\section{Speculation}

Anaerobic metabolism may partially account for the increased transport in newborn rats. Future studies may reveal whether the rate of anaerobic transport decreases in a pattern similar to the overall decrease in transport observed in the neonatal rat with maturation.

Intestinal transport has been observed to be maximal for both amino acids $(10,16,22,26)$ and sugars (9) immediately after birth. The decreased accumulation of neutral amino acids in adult rat small intestine appears to be due to the disappearance of transport sites found in the small intestine of newborn rats, rather than the presence in young animals of structurally modified transport carriers with a more efficient binding capacity $(6,26)$. It has been demonstrated that the active transport of amino acids (22) in chick small intestine soon after hatching was not completely dependent on aerobic metabolism. Measurements of glycolysis in chicken (22) and rabbit (37) small intestine have shown a decrease in the rate of anaerobic glycolysis during the first week after birth. Kidney slices from newborn rats have been shown to achieve a higher net uptake of amino acids than mature tissue after prolonged incubation $(3,4,33,35)$. Baerlocher et al. (5) have demonstrated an adaptive advantage in the presence of anoxia held by immature kidney over mature tissue. Therefore, it would be of primary physiologic interest to determine whether the increased rate of active intestinal transport in the newborn rat is energized by a specialized mechanism.

In continuing our study of transport in the 2-day-old rat 
intestine $(16,17,26)$ we are now examining the metabolic properties of the increased intracellular accumulation of a prototype amino acid (L-leucine) and sugar (D-galactose) in order to determine whether the transport properties of these metabolites in neonates are fundamentally different from those found in adult animals.

\section{MATERIALS AND METHODS}

Wistar strain rats of both sexes were used as a source of the 2-day-old intestinal segments. Male Wistar strain rats weighing $150-200 \mathrm{~g}$ were used as a source of adult intestine. All animals were killed by decapitation, the small intestine quickly removed, placed in saline or isotonic choline chloride, and gassed with nitrogen or oxygen. The 2-day-old intestine was split longitudinally while immersed in the isotonic medium, which yielded intestinal segments essentially free of luminal contents. The adult intestine was everted, divided into segments, randomized, and tied into sacs approximately $9 \mathrm{~cm}$ in length according to the method of Wilson and Wiseman (36), or everted, split longitudinally, divided into $7-\mathrm{cm}$ segments, and randomized in a modification of the method of Agar et al. (1).

The method employed for preincubation of the 2-day-old segments was $5 \mathrm{ml}$ oxygenated Krebs-Ringer-Tris buffer, $\mathrm{pH}$ 7.4, containing $118 \mathrm{mM} \mathrm{NaCl}, 25 \mathrm{mM}$ Tris- $\mathrm{HCl}, 4.7 \mathrm{mM} \mathrm{KCl}$,

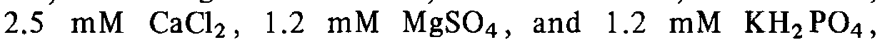
without or with inhibitors. The segments were preincubated at $37^{\circ}$ for the indicated time in a water bath oscillating 50-75 times/min. After preincubation, the segments were washed in saline or isotonic choline chloride (continuously gassing with either nitrogen or oxygen), drained, and reincubated in a $37^{\circ}$ water bath with shaking for 5 to $30 \mathrm{~min}$. The medium employed for incubation, in studies without or with preincubation, was $5 \mathrm{ml}$ oxygen- or nitrogen-gassed Krebs-Ringer-Tris buffer, pH 7.4, as described above, containing 8,000-15,000 $\mathrm{cpm} / \mathrm{ml}$ (methoxy- ${ }^{3} \mathrm{H}$ ) inulin and ${ }^{14} \mathrm{C}$ radioactive $(8,000-$ $15,000 \mathrm{cpm} / \mathrm{ml}$ ) and $1 \mathrm{mM}$ nonradioactive L-leucine or D-galactose. The radioactive leucine and galactose were uniformly labeled and reported to be at least $98 \%$ pure by dilution analysis, paper chromatography, and paper electrophoresis. The everted sacs or segments were incubated for 5 min in a medium identical with that used for the 2-day-old intestinal segments.

In the studies using $\mathrm{Na}^{+}$-free incubation media, choline chloride was used as an isotonic replacement for the $\mathrm{NaCl}$ of the Krebs-Ringer-Tris buffer. The $\mathrm{Na}^{+}$concentration of the incubation media was determined by direct analysis in a Coleman flame photometer. The maintenance of an essentially $\mathrm{Na}^{+}$-free environment during these studies was confirmed by the finding that only $1.20 \pm 0.1 \mathrm{mM} \mathrm{Na}^{+}$(mean $\pm 1 \mathrm{SEM}, \mathrm{n}=$ 30) was present in the incubation medium after incubation.

After the incubation the everted sacs and intestinal segments were removed from the flasks and drained. The sacs were opened, the inside medium drained, and the empty sacs were washed, blotted, and weighed. Similarly, the adult and 2-day-old segments were washed, blotted, and weighed. The residual tissue was homogenized in 4 times its weight of $5 \%$ trichloroacetic acid to make a $20 \%$ homogenate. The homogenate was centrifuged, and aliquots of the supernatant were counted in a Tri-Carb liquid scintillation spectrometer (38) in a system containing xylene-dioxane-ethanol $(5: 5: 3)$, naphthalene (40 g/liter), 2,5-diphenyloxazole (5 g/liter), and 1,4-bis[2-(5-phenyloxazolyl] benzene (100 g/liter). The spectrometer was adjusted to permit $60 \%{ }^{14} \mathrm{C}$ efficiency, $22 \%{ }^{3} \mathrm{H}$ efficiency, less than $0.01 \%{ }^{3} \mathrm{H}$ efficiency on the ${ }^{14} \mathrm{C}$ channel, and $10 \%{ }^{14} \mathrm{C}$ efficiency on the ${ }^{3} \mathrm{H}$ channel. An extracellular fluid space was calculated from the distribution space of $\left({ }^{3} \mathrm{H}\right)$ inulin (corrected for $10 \%{ }^{14} \mathrm{C}$ contribution) in the residual tissue and expressed as percentage of tissue wet weight
(28). Amino acid and sugar transport values are expressed as intracellular accumulation, which is defined as the millimolar concentration of the amino acid or sugar in the cellular water after a given incubation period. This parameter was calculated on the basis of a modification of a formula used by Crane and Mandelstam (12), which now takes the following form: millimolar (cellular water) $=$ (millimolar homogenate supernatant $X$ homogenate volume) - (extracellular space $X$ tissue wet weight $\times 0.8 \times$ millimolar medium $) /(1-$ extracellular space) $X$ (tissue wet weight $X 0.8$ ).

The source and specific activity of the radioactive compounds used in this study were: uniformly labeled $\mathrm{L}-\left({ }^{14} \mathrm{C}\right)$ leucine $(342 \mathrm{mCi} / \mathrm{mmol})$, uniformly labeled $\mathrm{D}-\left({ }^{14} \mathrm{C}\right)$ galactose (43 $\mathrm{mCi} / \mathrm{mmol})(39)$, and $\left(\right.$ methoxy $\left.{ }^{3} \mathrm{H}\right)$ inulin $(672 \mathrm{mCi} /$ mmol) (40). Ethacrynic acid was used as the pure powder and was kindly supplied by Merck, Sharp, and Dohme Research Laboratories (41). The sodium iodoacetate, $N$-ethylmaleimide, dinitrophenol, sodium, arsenate, sodium fluoride, and ouabain were obtained from Sigma Chemical Company (42).

\section{RESULTS}

Since the active transport of neutral amino acids $(13,25$, $27)$ and sugars $(7,11)$ in adult intestine has been shown to be $\mathrm{Na}^{+}$dependent, it was important to determine whether the active accumulation of leucine and galactose in 2-day-old rat intestine also requires the presence of extracellular $\mathrm{Na}^{+}$. The comparative effect of $\mathrm{Na}^{+}$on the intracellular accumulation of $1 \mathrm{mM} \mathrm{L}$-leucine and $1 \mathrm{mM} \mathrm{D}$-galactose at 5 and $30 \mathrm{~min}$ is shown in Table 1. The times were chosen to represent initial velocity and steady state conditions (26). In the absence of extracellular $\mathrm{Na}^{+}$, leucine intracellular accumulation was reduced $78 \%$ after $5 \mathrm{~min}$ of incubation and $82 \%$ after $30 \mathrm{~min}$. The uptake of $\mathrm{D}$-galactose from a $\mathrm{Na}^{+}$-free medium was reduced $95 \%$ after $5 \mathrm{~min}$ of incubation and $90 \%$ after $30 \mathrm{~min}$. These results suggest that the active intracellular accumulation of neutral amino acids and sugars in 2-day-old rats is a $\mathrm{Na}^{+}$-dependent process.

Table 2 demonstrates the effect of a 5 -min incubation with

Table 1. Effect of $\mathrm{Na}^{+}$on intracellular accumulation of L-leucine and D-galactose in intestine of 2-day-old rats ${ }^{1}$

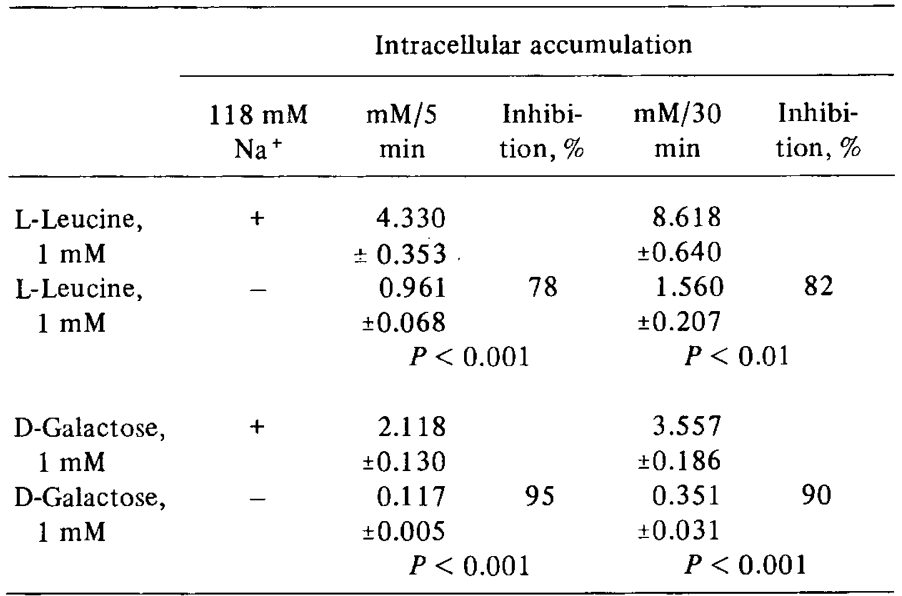

${ }^{1}$ Intestinal segments were incubated for 5 or $30 \mathrm{~min}$ at $37^{\circ}$ in a Krebs-Tris- $\mathrm{Na}^{+}$medium or a Krebs-Tris-choline medium containing 1 $\mathrm{mM}$ L-leucine or $1 \mathrm{mM} D$-galactose. Each value represents the mean \pm 1 SEM from at least four individual experiments. A paired-difference $t$ test was used to obtain the probability values and a $P$ of 0.05 or less was interpreted as indicating a significant inhibition. The percentage of inhibition values were obtained by dividing the average uptake in the Krebs-Tris-choline chloride medium by the average uptake in the Krebs-Tris- $\mathrm{Na}^{+}$medium and subtracting from $100 \%$. The percentage of inhibitions and $P$ values represented paired experiments. Control values as given may represent values from several experiments. 
Table 2. Effect of metabolic inhibitors on intracellular accumulation of $1 \mathrm{mM}$ L-leucine and $1 \mathrm{mM} D$-galactose in intestine of 2-day-old rats

\begin{tabular}{|c|c|c|c|c|c|c|}
\hline \multirow[b]{2}{*}{ Inhibitor } & \multicolumn{6}{|c|}{ Intracellular accumulation } \\
\hline & $\begin{array}{c}\text { Leucine, } \\
\mathrm{mM} / \\
5 \mathrm{~min}\end{array}$ & $\begin{array}{c}\text { Inhibi- } \\
\text { tion, } \\
\%\end{array}$ & $P$ & $\begin{array}{c}\text { Galactose, } \\
\mathrm{mM} / \\
5 \mathrm{~min}\end{array}$ & $\begin{array}{c}\text { Inhibi- } \\
\text { tion, } \\
\%\end{array}$ & $P$ \\
\hline \multirow[t]{2}{*}{ None } & 4.863 & & & 1.978 & & \\
\hline & \pm 0.248 & & & \pm 0.073 & & \\
\hline \multirow{2}{*}{$\begin{array}{l}\text { Sodium iodoace- } \\
\text { tate, } 1.0 \mathrm{mM}\end{array}$} & 3.451 & 15 & 0.05 & 1.709 & 10 & \\
\hline & \pm 0.224 & & & \pm 0.114 & & \\
\hline \multirow{2}{*}{$\begin{array}{l}N \text {-Ethylmalei- } \\
\text { mide, } 1.0 \mathrm{mM}\end{array}$} & 3.389 & 38 & 0.001 & 1.538 & 17 & 0.05 \\
\hline & \pm 0.436 & & & \pm 0.120 & & \\
\hline \multirow{2}{*}{$\begin{array}{l}\text { Dinitrophenol, } \\
0.4 \mathrm{mM}\end{array}$} & 3.207 & 41 & 0.001 & 1.420 & 23 & 0.01 \\
\hline & \pm 0.180 & & & \pm 0.123 & & \\
\hline \multirow{2}{*}{$\begin{array}{l}\text { Sodium arsenate, } \\
10.0 \mathrm{mM}\end{array}$} & 3.423 & 16 & 0.05 & 1.747 & 8 & \\
\hline & \pm 0.224 & & & \pm 0.056 & & \\
\hline \multirow{2}{*}{$\begin{array}{l}\text { Sodium fluoride, } \\
10.0 \mathrm{mM}\end{array}$} & 3.798 & 7 & & 1.867 & 2 & \\
\hline & \pm 0.218 & & & \pm 0.075 & & \\
\hline \multirow[t]{2}{*}{ Ouabain, $1.0 \mathrm{mM}$} & 4.067 & 29 & 0.01 & 1.611 & 21 & 0.05 \\
\hline & \pm 0.201 & . & & \pm 0.154 & & \\
\hline
\end{tabular}

${ }^{1}$ Intestinal segments were incubated for $5 \mathrm{~min}$ at $37^{\circ}$ in a Krebs-Tris medium containing $1 \mathrm{mM} \mathrm{L}$-leucine or $1 \mathrm{mM} \mathrm{D}$-galactose without or with the various inhibitors at the indicated concentrations. Each value represents the mean \pm 1 SEM from at least six individual experiments. Percentage of inhibition and probability values were obtained as described in Table 1.

various metabolic inhibitors on the intracellular accumulation of leucine and galactose in 2-day-old rat intestine. The sulfhydryl inhibitors, iodoacetate and $N$-ethylmaleimide, reduced the intracellular accumulation of leucine $15 \%$ and $38 \%$, respectively. Galactose uptake was inhibited by $N$-ethylmaleimide $17 \%$, but was not significantly decreased by iodoacetate. Dinitrophenol, a potent inhibitor of oxidative phosphorylation, reduced the intracellular accumulation of leucine $41 \%$ and galactose $23 \%$. The inhibitors of glycolysis, sodium arsenate (2) and sodium fluoride (32), decreased the uptake of L-leucine $16 \%$ while galactose uptake was not significantly inhibited. Ouabain was used as an inhibitor of the $\left(\mathrm{Na}^{+}\right.$, $\mathrm{K}^{+}$)-dependent ATPase (23) and inhibited leucine uptake by $29 \%$ and galactose uptake $21 \%$. This inhibition was substantially less than the observed in a $\mathrm{Na}^{+}$-free medium. These results may be a reflection of the relative inaccessability of the serosal membrane in intact intestine, as ouabain has been observed to produce a much larger inhibition of leucine uptake in isolated intestinal epithelial cells than that produced by the absence of $\mathrm{Na}^{+}$(27).

As shown in Table 1, the intracellular accumulation of amino acids and sugars in 2-day-old rat intestine is extremely $\mathrm{Na}^{+}$dependent. The inhibition of active uptake of amino acids in adults by metabolic inhibitors is thought to be ultimately a reflection of the inhibition of ATP production required to maintain the $\mathrm{Na}^{+}$gradient across the cell membrane (30). In order to allow sufficient time for the $\mathrm{Na}^{+}$gradient across the cell to be dissipated a study was made of the effect of preincubating with the inhibitors at varying time periods (Tables 3 and 4). Generally, the percentage of inhibition of uptake of both leucine and galactose increased with time of preincubation. Ethacrynic acid $(2 \mathrm{mM})$ was used in addition to ouabain as an inhibitor of $\left(\mathrm{Na}^{+}, \mathrm{K}^{+}\right)$-dependent ATPase (23). Ethacrynic acid has been shown to inhibit $\mathrm{Na}^{+}$absorption in the Loop of Henle (18) and in hamster intestine (8) and to inhibit the extrusion of $\mathrm{Na}^{+}$from guinea pig kidney cortex slices (23). All inhibitors tested inhibited L-leucine and D-galactose uptake at least $50 \%$ after a 30 -min preincubation except ouabain, which inhibited leucine $38 \%$ and galactose $37 \%$. The results suggest strongly that the energy required for the intracellular accumulation of leucine and galactose is derived in part from aerobic metabolism and is consistent with the $\mathrm{Na}^{+}$gradient hypothesis for the energization of active transport.

A progressive dependence on aerobic metabolism for the transport of L-valine has been demonstrated in the maturing chick intestine (22). As adult rat intestine has been shown to be extremely sensitive to anaerobiosis $(24,27)$, it was of interest to investigate whether 2-day-old intestinal tissue differed from adult tissue in its capacity to transport amino acids anaerobically. The effect of anaerobiosis on the intracellular accumulation of $1 \mathrm{mM}$ leucine by everted intestinal sacs and segments from adults and 2-day-old rat intestinal segments at 5 and $30 \mathrm{~min}$ is compared in Table 5. Leucine intracellular accumulation in adult sacs was shown to be inhibited $44 \%$ and $39 \%$ in adult segments after an incubation time of $5 \mathrm{~min}$, whereas uptake in the 2-day-old rat intestine was inhibited only $12 \%$. All were inhibited more than $70 \%$, however, after $30 \mathrm{~min}$ of incubation.

The anaerobic transport of amino acids in intestine is apparently unique to immature animals (Table 5) (22). Therefore, to further elucidate the characteristics of the

Table 3. Effect of preincubation with metabolic inhibitors on intracellular accumulation of $1 \mathrm{mML}$-leucine in intestine of 2-day-old rats ${ }^{1}$

\begin{tabular}{|c|c|c|c|c|c|c|}
\hline \multirow[b]{3}{*}{ Inhibitor } & \multicolumn{6}{|c|}{ Intracellular accumulation } \\
\hline & \multicolumn{2}{|c|}{$\begin{array}{l}5 \text {-min pre- } \\
\text { incubation }\end{array}$} & \multicolumn{2}{|c|}{$\begin{array}{l}\text { 15-min pre- } \\
\text { incubation }\end{array}$} & \multicolumn{2}{|c|}{$\begin{array}{l}\text { 30-min pre- } \\
\text { incubation }\end{array}$} \\
\hline & $\begin{array}{c}\mathrm{mM} / 5 \\
\min \end{array}$ & $\begin{array}{l}\text { Inhibi- } \\
\text { tion, } \\
\%\end{array}$ & $\underset{\mathrm{min}}{\mathrm{mM} / 5}$ & $\begin{array}{l}\text { Inhibi- } \\
\text { tion, } \\
\%\end{array}$ & $\underset{\mathrm{min}}{\mathrm{mM} / 5}$ & $\begin{array}{c}\text { Inhibi- } \\
\text { tion } \\
\%\end{array}$ \\
\hline None & $\begin{array}{r}5.197 \\
\pm 0.201\end{array}$ & & $\begin{array}{r}5.164 \\
\pm 0.204\end{array}$ & & $\begin{array}{r}4.817 \\
\pm 0.269\end{array}$ & \\
\hline $\begin{array}{l}\text { Sodium iodoace- } \\
\text { tate, } 1.0 \mathrm{mM}\end{array}$ & $\begin{array}{r}4.479 \\
\pm 0.133 \\
P<\end{array}$ & $\begin{array}{r}21 \\
.01\end{array}$ & $\begin{aligned} & 3.142 \\
& \pm 0.215 \\
& P<0\end{aligned}$ & $\begin{array}{r}38 \\
.01\end{array}$ & $\begin{array}{r}2.332 \\
\pm 0.117 \\
P<0\end{array}$ & $\begin{array}{r}52 \\
.01\end{array}$ \\
\hline $\begin{array}{l}N \text {-Ethylmalei- } \\
\text { mide, } 1.0 \mathrm{mM}\end{array}$ & $\begin{array}{c}2.345 \\
\pm 0.217 \\
P<\end{array}$ & $\begin{array}{r}56 \\
.001\end{array}$ & $\begin{array}{r}1.144 \\
\pm 0.086 \\
P<0\end{array}$ & $\begin{array}{r}78 \\
.01\end{array}$ & $\begin{array}{c}0.769 \\
\pm 0.060 \\
P<\end{array}$ & $\begin{array}{r}84 \\
.001\end{array}$ \\
\hline $\begin{array}{l}\text { Dinitrophenol, } \\
0.4 \mathrm{mM}\end{array}$ & $\begin{array}{r}3.799 \\
\pm 0.301 \\
P<\end{array}$ & $\begin{array}{r}28 \\
.02\end{array}$ & $\begin{array}{r}2.625 \\
\pm 0.224 \\
P<0\end{array}$ & $\begin{array}{r}50 \\
.001\end{array}$ & $\begin{array}{c}1.968 \\
\pm 0.179 \\
P<0\end{array}$ & $\begin{array}{r}59 \\
.001\end{array}$ \\
\hline $\begin{array}{l}\text { Sodium arsenate, } \\
10.0 \mathrm{mM}\end{array}$ & $\begin{array}{r}3.739 \\
\pm 0.159 \\
P<\end{array}$ & $\begin{array}{r}34 \\
.01\end{array}$ & $\begin{array}{r}2.445 \\
\pm 0.154 \\
P<0\end{array}$ & $\begin{array}{r}52 \\
.001\end{array}$ & $\begin{array}{r}1.607 \\
\pm 0.078 \\
P<0\end{array}$ & $\begin{array}{r}77 \\
.001\end{array}$ \\
\hline $\begin{array}{l}\text { Sodium fluoride, } \\
10.0 \mathrm{mM}\end{array}$ & $\begin{array}{r}3.737 \\
\pm 0.374 \\
P<\end{array}$ & $\begin{array}{r}34 \\
.02\end{array}$ & $\begin{array}{c}2.745 \\
\pm 0.071 \\
P<0\end{array}$ & $\begin{array}{r}46 \\
.001\end{array}$ & $\begin{array}{r}2.286 \\
\pm 0.072 \\
P<0\end{array}$ & $\begin{array}{r}53 \\
.01\end{array}$ \\
\hline $\begin{array}{l}\text { Ethacrynic acid, } \\
2.0 \mathrm{mM}\end{array}$ & $\begin{array}{r}3.646 \\
\pm 0.211 \\
P<\end{array}$ & $\begin{array}{r}21 \\
.05\end{array}$ & $\begin{array}{c}2.280 \\
\pm 0.076 \\
P<0\end{array}$ & $\begin{array}{r}58 \\
.001\end{array}$ & $\begin{array}{r}1.324 \\
\pm 0.058 \\
P<0\end{array}$ & $\begin{array}{r}71 \\
.001\end{array}$ \\
\hline Ouabain, $1.0 \mathrm{mM}$ & $\begin{array}{r}3.191 \\
\pm 0.199 \\
P<\end{array}$ & $\begin{array}{r}39 \\
.01\end{array}$ & $\begin{array}{c}3.114 \\
\pm 0.211 \\
P<0\end{array}$ & $\begin{array}{r}40 \\
.01\end{array}$ & $\begin{array}{r}2.942 \\
\pm 0.126 \\
\quad P<0\end{array}$ & $\begin{array}{r}38 \\
.01\end{array}$ \\
\hline
\end{tabular}

${ }^{1}$ Intestinal segments were preincubated at $37^{\circ}$ in a Krebs-Tris medium without or with the inhibitors at the indicated concentrations for 5,15 , or $30 \mathrm{~min}$. At the end of the preincubation the segments were removed, washed in oxygenated isotonic $\mathrm{NaCl}$ and reincubated for 5 $\mathrm{min}$ in a Krebs-Tris medium containing $1 \mathrm{mM}$ L-leucine. Each value represents the mean \pm 1 SEM from at least six individual experiments. Percentage of inhibition and probability values were obtained as described in Table 1. 
Table 4. Effect of preincubation with metabolic inhibitors on intracellular accumulation of $1 \mathrm{mM} \mathrm{D}$-galactose in intestine of 2-day-old rats ${ }^{1}$

Intracellular accumulation

\begin{tabular}{|c|c|c|c|c|c|c|}
\hline \multirow[b]{2}{*}{ Inhibitor } & \multicolumn{2}{|c|}{$\begin{array}{l}5 \text {-min pre- } \\
\text { incubation }\end{array}$} & \multicolumn{2}{|c|}{$\begin{array}{l}\text { 15-min pre- } \\
\text { incubation }\end{array}$} & \multicolumn{2}{|c|}{$\begin{array}{l}30 \text {-min pre- } \\
\text { incubation }\end{array}$} \\
\hline & $\begin{array}{c}\mathrm{mM} / 5 \\
\mathrm{~min}\end{array}$ & $\begin{array}{c}\text { Inhibi- } \\
\text { tion, } \\
\%\end{array}$ & $\begin{array}{c}\mathrm{mM} / 5 \\
\mathrm{~min}\end{array}$ & $\begin{array}{c}\text { Inhibi- } \\
\text { tion, } \\
\%\end{array}$ & $\begin{array}{c}\mathrm{mM} / 5 \\
\mathrm{~min}\end{array}$ & $\begin{array}{c}\text { Inhibi- } \\
\text { tion } \\
\%\end{array}$ \\
\hline None (18) & $\begin{array}{r}2.106 \\
\pm 0.105\end{array}$ & & $\begin{array}{r}2.151 \\
\pm 0.076\end{array}$ & & $\begin{array}{r}2.336 \\
\pm 0.096\end{array}$ & \\
\hline $\begin{array}{l}\text { Sodium iodoace- } \\
\text { tate }(6), 1.0 \mathrm{mM}\end{array}$ & $\begin{array}{r}2.052 \\
\pm 0.111\end{array}$ & 4 & $\begin{array}{c}1.496 \\
\pm 0.121 \\
P<0\end{array}$ & $\begin{array}{r}38 \\
0.001\end{array}$ & $\begin{array}{c}1.160 \\
\pm 0.086 \\
P<\end{array}$ & $\begin{array}{r}54 \\
.001\end{array}$ \\
\hline $\begin{array}{l}N \text {-Ethylmaleimide } \\
(6), 1.0 \mathrm{mM}\end{array}$ & $\begin{array}{r}1.132 \\
\pm 0.072 \\
P<\end{array}$ & $\begin{array}{r}46 \\
0.01\end{array}$ & $\begin{array}{c}0.706 \\
\pm 0.121 \\
P<0\end{array}$ & $\begin{array}{r}64 \\
0.001\end{array}$ & $\begin{array}{c}0.553 \\
\pm 0.021 \\
P<\end{array}$ & $\begin{array}{r}77 \\
.001\end{array}$ \\
\hline $\begin{array}{l}\text { Dinitrophenol } \\
\text { (11), } 0.4 \mathrm{mM}\end{array}$ & $\begin{array}{r}1.653 \\
\pm 0.103 \\
P<\end{array}$ & $\begin{array}{r}21 \\
0.01\end{array}$ & $\begin{array}{r}1.425 \\
\pm 0.088 \\
P<0\end{array}$ & $\begin{array}{r}29 \\
0.001\end{array}$ & $\begin{array}{r}1.120 \\
\pm 0.096 \\
P<\end{array}$ & $\begin{array}{r}50 \\
.001\end{array}$ \\
\hline $\begin{array}{l}\text { Sodium arsenate } \\
(8), 10.0 \mathrm{mM}\end{array}$ & $\begin{array}{r}1.694 \\
\pm 0.146 \\
P<\end{array}$ & $\begin{array}{r}22 \\
0.01\end{array}$ & $\begin{array}{r}1.536 \\
\pm 0.203 \\
P<0\end{array}$ & $\begin{array}{r}37 \\
0.01\end{array}$ & $\begin{array}{r}1.093 \\
\pm 0.094 \\
P<\end{array}$ & $\begin{array}{r}56 \\
.001\end{array}$ \\
\hline $\begin{array}{r}\text { Sodium fluoride } \\
\text { (11), } 10.0 \mathrm{mM}\end{array}$ & $\begin{array}{r}1.609 \\
\pm 0.138 \\
P<\end{array}$ & $\begin{array}{r}24 \\
0.01\end{array}$ & $\begin{array}{c}1.213 \\
\pm 0.126 \\
P<0\end{array}$ & $\begin{array}{r}46 \\
0.001\end{array}$ & $\begin{array}{c}0.953 \\
\pm 0.134 \\
P<\end{array}$ & $\begin{array}{r}59 \\
.001\end{array}$ \\
\hline $\begin{array}{l}\text { Ethacrynic acid } \\
\text { (4), } 2.0 \mathrm{mM}\end{array}$ & $\begin{array}{r}1.337 \\
\pm 0.101 \\
P<\end{array}$ & $\begin{array}{r}33 \\
0.05\end{array}$ & $\begin{array}{r}1.234 \\
\pm 0.186 \\
\quad P<0\end{array}$ & $\begin{array}{r}36 \\
0.02\end{array}$ & $\begin{array}{r}0.709 \\
\pm 0.103 \\
P<\end{array}$ & $\begin{array}{r}63 \\
.01\end{array}$ \\
\hline $\begin{array}{l}\text { Ouabain (8), } \\
1.0 \mathrm{mM}\end{array}$ & $\begin{array}{r}1.659 \\
\pm 0.083 \\
P<\end{array}$ & $\begin{array}{r}22 \\
0.02\end{array}$ & $\begin{array}{c}1.441 \\
\pm 0.072 \\
P<0\end{array}$ & $\begin{array}{r}30 \\
0.01\end{array}$ & $\begin{array}{c}1.531 \\
\pm 0.103 \\
P<\end{array}$ & $\begin{array}{r}37 \\
.001\end{array}$ \\
\hline
\end{tabular}

${ }^{1}$ The methodology is the same as in Table 3 with the exception of the substitution of $1 \mathrm{mM} \mathrm{D}$-galactose for L-leucine in the incubation medium. The number of individual experiments is shown in parentheses.

Table 5. Anaerobic intracellular accumulation of $1 \mathrm{mM} L$-leucine in rats as function of time ${ }^{1}$

\begin{tabular}{|c|c|c|c|c|c|c|}
\hline \multirow[b]{2}{*}{$\begin{array}{l}\text { Atmo- } \\
\text { sphere }\end{array}$} & \multicolumn{2}{|c|}{ 2-day-old } & \multicolumn{2}{|c|}{ Adult (sacs) } & \multicolumn{2}{|c|}{ Adult (segments) } \\
\hline & $\begin{array}{c}\mathrm{mM} / 5 \\
\mathrm{~min}\end{array}$ & $\begin{array}{l}\text { Inhibi- } \\
\text { tion, \% }\end{array}$ & $\begin{array}{c}\mathrm{mM} / 5 \\
\min \end{array}$ & $\begin{array}{l}\text { Inhibi- } \\
\text { tion, \% }\end{array}$ & $\underset{\mathrm{mM} / 5}{\mathrm{~min}}$ & $\begin{array}{l}\text { Inhibi- } \\
\text { tion, \% }\end{array}$ \\
\hline \multirow[t]{2}{*}{$\mathrm{O}_{2}$} & 4.330 & & 2.349 & & 2.106 & \\
\hline & \pm 0.353 & & \pm 0.178 & & \pm 0.142 & \\
\hline \multirow[t]{4}{*}{$\mathrm{N}_{2}$} & 3.801 & 12 & 1.316 & 44 & 1.328 & 39 \\
\hline & \pm 0.427 & & \pm 0.053 & & \pm 0.094 & \\
\hline & $P<$ & & $P<$ & 001 & $P<$ & \\
\hline & $\begin{array}{c}\mathrm{mM} / 30 \\
\mathrm{~min}\end{array}$ & & $\begin{array}{c}\mathrm{mM} / 30 \\
\mathrm{~min}\end{array}$ & & $\underset{\min }{\mathrm{mM} / 30}$ & \\
\hline \multirow[t]{2}{*}{$\mathrm{O}_{2}$} & 8.839 & & 2.529 & & 4.348 & \\
\hline & \pm 0.459 & & \pm 0.183 & & \pm 0.077 & \\
\hline \multirow[t]{3}{*}{$\mathrm{N}_{2}$} & 1.722 & 81 & 0.681 & 73 & 1.057 & 76 \\
\hline & \multirow{2}{*}{\multicolumn{2}{|c|}{$\begin{array}{l} \pm 0.129 \\
\quad P<0.001\end{array}$}} & \pm 0.069 & & \pm 0.031 & \\
\hline & & & \multicolumn{2}{|c|}{$P<0.001$} & \multicolumn{2}{|c|}{$P<0.001$} \\
\hline
\end{tabular}

'Intestinal segments from 2-day-old rats and everted sacs and segments from adult rats were incubated 5 or $30 \mathrm{~min}$ at $37^{\circ}$ in a Krebs-Tris medium containing $1 \mathrm{mM}$ L-leucine under an $\mathrm{O}_{2}$ or $\mathrm{N}_{2}$ atmosphere. Each value represents the mean \pm 1 SEM from at least seven individual experiments. Percentage of inhibition and probability values were obtained as described in Table 1.
Table 6. Effect of $\mathrm{Na}^{+}$on anaerobic intra 'ellular accumulation of $L$-leucine and D-galacto: $\sim$ in intestine of 2-day-old rats 1

\begin{tabular}{|c|c|c|c|c|c|}
\hline & \multicolumn{5}{|c|}{ Intracellular accumulation } \\
\hline & $\begin{array}{c}118 \mathrm{mM} \\
\mathrm{Na}^{+}\end{array}$ & $\underset{\mathrm{min}}{\mathrm{mM} / 5}$ & $\begin{array}{l}\text { Inhibi- } \\
\text { tion, \% }\end{array}$ & $\underset{\mathrm{min}}{\mathrm{mM} / 30}$ & $\begin{array}{l}\text { Inhibi- } \\
\text { tion, } \%\end{array}$ \\
\hline $\begin{array}{l}\text { L-Leucine, } \\
1 \mathrm{mM}\end{array}$ & + & $\begin{array}{r}3.801 \\
\pm 0.427\end{array}$ & & $\begin{array}{r}1.722 \\
\pm 0.129\end{array}$ & \\
\hline $\begin{array}{l}\text { L-Leucine, } \\
1 \mathrm{mM}\end{array}$ & - & $\begin{array}{r}0.935 \\
\pm 0.083 \\
P<\end{array}$ & $\begin{array}{r}75 \\
.001\end{array}$ & $\begin{array}{r}0.739 \\
\pm 0.040 \\
P<\end{array}$ & $\begin{array}{r}57 \\
.001\end{array}$ \\
\hline $\begin{array}{c}\text { D-Galactose, } \\
1 \mathrm{mM}\end{array}$ & + & $\begin{array}{r}1.817 \\
\pm 0.196\end{array}$ & & $\begin{array}{r}1.816 \\
\pm 0.178\end{array}$ & \\
\hline $\begin{array}{l}\text { D-Galactose, } \\
1 \mathrm{mM}\end{array}$ & - & $\begin{array}{r}0.161 \\
\pm 0.008 \\
P<\end{array}$ & $\begin{array}{r}91 \\
.001\end{array}$ & $\begin{array}{r}0.366 \\
\pm 0.019 \\
P<\end{array}$ & $\begin{array}{r}80 \\
.001\end{array}$ \\
\hline
\end{tabular}

${ }^{1}$ Intestinal segments were incubated for 5 or $30 \mathrm{~min}$ at $37^{\circ}$ in a $\mathrm{Krebs}^{-\mathrm{Tris}-\mathrm{Na}^{+}}$medium or Krebs-Tris-choline medium containing $1 \mathrm{mM}$ L-leucine or $1 \mathrm{mM}$ D-galactose under a $\mathrm{N}_{2}$ atmosphere. Each value represents the mean \pm 1 SEM from at least seven individual experiments. Percentage of inhibition and probability values were obtained as described in Table 1.

anaerobic intracellular accumulation of leucine and galactose, the effect of $\mathrm{Na}^{+}$on this anaerobically energized process was studied (Table 6). In the $\mathrm{Na}^{+}$-free medium after 5 min of incubation anaerobic leucine uptake was reduced $75 \%$ and did not reach values greater than unity in the absence of extracellular $\mathrm{Na}^{+}$. Galactose uptake was inhibited $90 \%$ after 5 min of incubation. In a $\mathrm{Na}^{+}$-free medium, the intracellular accumulation of leucine and galactose was reduced significantly after a 30 -min anaerobic incubation (Table 6).

In order to characterize the possible energization of the anaerobic uptake of leucine and galactose, the intestinal segments from 2-day-old rats were preincubated for $15 \mathrm{~min}$ aerobically with various inhibitors before a 5-min anaerobic incubation with leucine or galactose and the resultant accumulation was compared with that of segments preincubated in the Krebs-Tris medium alone, i.e, without inhibitors (Table 7). These results demonstrated an inhibition of anaerobic uptake that was generally of the same magnitude as the inhibition of intracellular accumulation under aerobic conditions when segments were preincubated with the same inhibitors for 15 min (compare Tables 3 and 4, 15-min preincubation). The greatest percentage of inhibition was produced by the sulfhydryl binder, $N$-ethylmaleimide, a compound which would be expected to act directly on the cell membrane rather than through a cellular mechanism.

\section{DISCUSSION}

The main objective of this study was to ascertain whether the increased transport in the 2-day-old rat intestine as compared with adult intestine is indicative of a vastly different energization process. Generally, the intracellular accumulation of leucine and galactose in 2-day-old rat intestine was shown to be the same as found in adult animal intestine in its response to metabolic inhibitors, sulhydryl binders, and in its $\mathrm{Na}^{+}$dependence $(7,12,14,24,27)$. The most significant difference observed between the transport characteristics of adult intestine and those of 2-day-old rat intestine was the level of active transport maintained by the young animal under anaerobic conditions. The inhibition of dinitrophenol and sodium arsenate suggests that, in part, the transport of leucine and galactose in the small intestine of the neonate is coupled 
Table 7. Effect of preincubation with metabolic inhibitors on anaerobic in tracellular accumulation of L-leucine and D-galactose in intestine of 2-day-old rats ${ }^{1}$

\begin{tabular}{|c|c|c|c|c|}
\hline \multirow[b]{2}{*}{ Inhibitor } & \multicolumn{2}{|c|}{$\begin{array}{l}\text { Intracellular accu- } \\
\text { mulation L-leucine }\end{array}$} & \multicolumn{2}{|c|}{$\begin{array}{l}\text { Intracellular accu- } \\
\text { mulation D-galactose }\end{array}$} \\
\hline & $\underset{\min }{\mathrm{mM} / 5}$ & $\begin{array}{l}\text { Inhibi- } \\
\text { tion, \% }\end{array}$ & $\underset{\mathrm{min}}{\mathrm{mM} / 5}$ & $\begin{array}{l}\text { Inhibi- } \\
\text { tion, \% }\end{array}$ \\
\hline None & $\begin{array}{r}3.529 \\
\pm 0.220\end{array}$ & & $\begin{array}{r}1.780 \\
\pm 0.101\end{array}$ & \\
\hline $\begin{array}{l}N \text {-Ethylmaleimide, } \\
1.0 \mathrm{mM}\end{array}$ & $\begin{array}{r}1.126 \\
\pm 0.117 \\
P<\end{array}$ & $\begin{array}{r}70 \\
001\end{array}$ & $\begin{array}{r}0.901 \\
\pm 0.044 \\
P<\end{array}$ & $\begin{array}{r}50 \\
.001\end{array}$ \\
\hline $\begin{array}{l}\text { Dinitrophenol, } \\
0.4 \mathrm{mM}\end{array}$ & $\begin{array}{r}1.616 \\
\pm 0.153 \\
P<\end{array}$ & $\begin{array}{r}57 \\
001\end{array}$ & $\begin{array}{r}1.072 \\
\pm 0.046 \\
P<\end{array}$ & $\begin{array}{r}41 \\
.001\end{array}$ \\
\hline $\begin{array}{l}\text { Sodium arsenate, } \\
10.0 \mathrm{mM}\end{array}$ & $\begin{array}{r}1.339 \\
\pm 0.107 \\
P<\end{array}$ & $\begin{array}{r}57 \\
001\end{array}$ & $\begin{array}{r}0.758 \\
\pm 0.037 \\
P<\end{array}$ & $\begin{array}{r}56 \\
001\end{array}$ \\
\hline $\begin{array}{l}\text { Sodium fluoride, } \\
10.0 \mathrm{mM}\end{array}$ & $\begin{array}{r}1.598 \\
\pm 0.109 \\
P<\end{array}$ & $\begin{array}{r}49 \\
01\end{array}$ & $\begin{array}{r}1.074 \\
\pm 0.106 \\
P<\end{array}$ & $\begin{array}{r}38 \\
01\end{array}$ \\
\hline $\begin{array}{l}\text { Ethacrynic acid, } \\
2.0 \mathrm{mM}\end{array}$ & $\begin{array}{r}2.320 \\
\pm 0.125 \\
P<\end{array}$ & 39 & $\begin{array}{r}1.229 \\
\pm 0.058 \\
P<\end{array}$ & $\begin{array}{r}32 \\
001\end{array}$ \\
\hline $\begin{array}{l}\text { Ouabain, } \\
1.0 \mathrm{mM}\end{array}$ & $\begin{array}{r}2.703 \\
\pm 0.234 \\
P<\end{array}$ & 29 & $\begin{array}{r}1.483 \\
\pm 0.079 \\
P<\end{array}$ & 18 \\
\hline
\end{tabular}

${ }^{1}$ Intestinal segments were preincubated at $37^{\circ}$ in an oxygenated Krebs-Tris medium without or with the inhibitors at the indicated concentrations for $15 \mathrm{~min}$. At the end of the preincubation, the segments were removed, washed in saline or isotonic choline chloride under a $\mathrm{N}_{2}$ atmosphere and reincubated for $5 \mathrm{~min}$ in $\mathrm{N}_{2}$-gassed media containing $1 \mathrm{mM}$ L-leucine or $1 \mathrm{mM} \mathrm{D}$-galactose. Each value represents the mean \pm 1 SEM from at least six individual experiments. Percentage of inhibition and probability values were obtained as described in Table 1.

to oxidative phosphorylation. However, the maintenance of active transport in neonates under conditions of anaerobiosis suggests that glycolysis can provide some of the energy necessary for transport. Even after an anerobic incubation as long as $30 \mathrm{~min}, 2$-day-old intestine is still capable of actively accumulating leucine. The active accumulation of amino acids under conditions of anaerobiosis has also been demonstrated in intestine of newborn chicks (22) and the kidney cortex of newborn Long-Evans rats (5). Other studies have shown that anaerobic metabolism can support transport under selective situations such as rat renal papillary slices (20) and glomeruli (21). Lowenstein et al. (20), who investigated the in vitro uptake of amino acids in renal papilla of rats, found that the accumulation of $\alpha$-aminoisobutyric acid fell only slightly in $\mathrm{O}_{2}$-deficient media and the accumulation of lysine remained the same, which indicated that the papilla was able to accumulate amino acids actively in vitro under conditions which simulate its in vivo environment, i.e., low $\mathrm{O}_{2}$ tensions and high sodium concentrations.

One of the most interesting characteristics of the anaerobic active accumulation of amino acids and sugars by the intestine of the 2-day-old rat was its complete dependence on extracellular $\mathrm{Na}^{+}$. It appears that active transport can be maintained both anaerobically and aerobically in the 2-day-old as opposed to a complete dependence on aerobic metabolism in the adult intestine, but both of these transport systems are equally $\mathrm{Na}^{+}$dependent.

Many of the characteristics of transport in the neonatal rat may be elucidated from these and previous studies $(3-5,16$, $17,26,33-35)$. Studies which involve the ontogeny of amino acid transport in rat kidney cortex have demonstrated short term amino acid transport to be lower in the kidney of newborn Wistar and Long-Evans rat $(3,4,34)$, although Segal (29) did not observe this in the Sprague-Dawley strain. However, the steady state ratios were shown to be greater in neonates than in adult kidney for all three strains $(3,4,29$, 34). There is evidence that these results reflect an impaired efflux in the newborn kidney $(5,29,35)$. This may be explained by the changing specific activity of transport sites during postnatal maturation concomitant with increasing membrane area $(15,19)$.

Two major transport systems for amino acids have been observed in intestines of 2 -day-old rats $(16,17)$. The most active of these systems has the highest affinity for neutral L-amino acids with lipophilic side chains. The second transport pathway has affinity for basic amino acids. The pathways mediating the transport of the acidic amino acids, imino acids, and $N$-substituted amino acids, however, have been shown to have minor activity in the neonatal rat (17).

The highest rate of active intestinal transport of both amino acids and sugars $(9,10,16,22,26)$ occurs immediately after birth and decreases as a function of age. On the basis of kinetic studies (26), the increase in intracellular accumulation of amino acids in the 2-day-old rat intestine can best be explained by the presence of more transport sites rather than by a more efficient binding by the carrier. The progressive decrease in transport activity may be a result of the disappearance of the widespread and locationally nonspecific transport sites found in the intestine of newborn rats $(6,26)$.

In this study, the metabolic properties of the increased rate of transport in the 2-day-old rat intestine were found to be similar to those of adult intestine. The uptake of leucine and galactose in the small intestine of the newborn rat was shown to be maintained concentratively under anaerobic conditions. Future studies may elucidate further characteristics of the energization and ontogeny of this system.

\section{SUMMARY}

The rate of transport for both amino acids and sugars has been observed to be greatest immediately after birth. The main objective of this study was to ascertain whether this increased transport in the 2-day-old rat intestine as compared with adult intestine is indicative of a basically different energization process. The intracellular accumulation of $1 \mathrm{mM}$ of a prototype neutral amino acid (L-leucine) and sugar (D-galactose) was measured at $5-\mathrm{min}$ initial velocities in the presence of inhibitors and after preincubation with inhibitors. The 2-day-old rat intestine was found to exhibit a similar $\mathrm{Na}^{+}$dependence to that found in the adult. Sulfhydryl binders (1 $\mathrm{mM} \mathrm{Na}$ iodoacetate, $1 \mathrm{mM} N$-ethylmaleimide) and inhibitors of aerobic and glycolytic metabolism $(0.4 \mathrm{mM}$ dinitrophenol, $10 \mathrm{mM} \mathrm{Na}$ arsenate, $10 \mathrm{mM} \mathrm{Na}$ fluoride) produced a similar decrease in the adults and 2-day-olds. The most significant difference between the transport characteristics of 2-day-olds and adults was the level of active transport maintained by the young animals under anaerobic conditions. Transport was inhibited only $12 \%$ in the newborn intestine, whereas adult intestine showed a $44 \%$ inhibition at initial velocities. This anaerobic transport was similarly $\mathrm{Na}^{+}$dependent and sensitive to the metabolic inhibitors. The results indicate that the increased transport found in newborn animals can be partially energized by anaerobic metabolism, but that the requirements for the maintenance of an active influx of sodium is similar in both neonates and adults.

\section{REFERENCES AND NOTES}

1. Agar, W. T., Hird, F. J. R., and Sidhu, G. S.: The uptake of amino acids by the intestine. Biochim. Biophys. Acta, 14: 80 (1954). 
2. Azzone, G. F., and Ernster, L.: Compartmentation of mitochondrial phosphorylations as disclosed by studies with arsenate. J. Biol. Chem., 236: 1510 (1961).

3. Baerlacher, K., Scriver, C. R., and Mohyuddin, F.: Ontogeny of iminoglycine transport in mammalian kidney. Proc. Natl. Acad. Sci. U. S. A., 65: 1009 (1970).

4. Baerlocher, K. E., Scriver, C. R., and Mohyuddin, F.: The ontogeny of amino acid transport in rat kidney. I. Effect on distribution ratios and intracellular metabolism of proline and glycine. Biochim. Biophys. Acta, 249: 353 (1971).

5. Baerlocher, K. E., Scriver, C. R., and Mohyuddin, F.: The ontogeny of amino acid transport in rat kidney. II. Kinetics of uptake and effect of anoxia. Biochim. Biophys. Acta, 249: 364 (1971).

6. Batt, E, R., and Schacter, D.: Developmental pattern of some intestinal transport mechanisms in newborn rats and mice. Amer. J. Physiol., 216: 1064 (1969).

7. Bihler, I., and Crane, R. K.: Studies on the mechanism of intestinal absorption of sugars, $V$. The influence of several cations and anions on the active transport, in vitro, by various preparations of hamster small intestine. Biochim. Biophys. Acta, 59: 78 (1962).

8. Binder, H. J., Katz, L. A., Spencer, R. P., and Spiro, H. M: The effect of inhibitors of renal transport on the small intestine. $J$. Clin. Invest., 45: 1854 (1966).

9. Bogner, P. H., and Haines, I. A.: Functional development of active sugar transport in the chick intestine. Amer. J. Physiol., 207: 37 (1964).

10. Butt, J. H., II, and Wilson, T. H.: Development of sugar and amino acid transport by intestine and yolk sac of the guinea pig. Amer. J. Physiol., 215: 1468 (1968).

11. Crane, R. K.: Uphill flow sugar from intestinal epithelial cells induced by reversal of the $\mathrm{Na}^{+}$-gradient: Its significance for the mechanism of the $\mathrm{Na}^{+}$-dependent active transport. Biochem. Biophys. Res. Commun., 17: 481 (1964).

12. Crane, R. K., and Mandelstam, P.: The active transport of sugars by various preparations of hamster intestine. Biochim. Biophys. Acta, 46: 460 (1960)

13. Csaky, T. Z.: Significance of sodium ions in active intestinal transport of non-electrolytes. Amer. J. Physiol., 201: 999 (1961).

14. Csaky, T, Z, and Zollicoffer, L.: Ionic effect on intestinal transport of glucose in the rat. Amer. J. Physiol., 198: 1056 (1960).

15. Fetterman, G. H., Shuplock, N. A., Phillipps, F. J., and Gregg, H. S.: The growth and maturation of human glomeruli and proximal convolutions from term to adulthood. Pediatrics, 35: 601 (1965).

16. Fitzgerald, J. F., Reiser, S., and Christiansen, P. A.: Developmental pattern of sugar and amino acid transport in the postnatal rat small intestine. Pediat. Res., 5: 698 (1971).

17. Fitzgerald, J. F., Reiser, S., and Christiansen, P. A.: Amino acid transport pathways in the neonatal rat. Pediat. Res., 6: 713 (1972).

18. Goldberg, M., McCuroy, D. K., Foltz, E. L., and Bluembe, L. W., Jr.: Effects of ethacrynic acid (a new saluretic agent) on renal diluting and concentrating mechanisms: Evidence for site of action in loop of Henle. J. Clin. Invest., 43: 201 (1964).

19. Horster, M., Kemler, B. J., and Valtin, H.: Intracortical distribution of number and volume of glomeruli during postnatal maturation in the dog. J. Clin. Invest. 50: 796 (1971).

20. Lowenstein, L. M., Smith, I., and Segal, S.: Amino acid transport in the rat renal papilla. Biochim. Biophys. Acta, 150: 73 (1968).

21. Mackenzie, S, and Scriver, C. R.: Transport of L-proline and $\alpha$-aminoisobutyric acid in the isolated rat kidney glomerulus. Biochim. Biophys. Acta, 241: 725 (1971).

22. Pratt, R. M., Jr., and Terner, C.: Development of amino acid transport by the small intestine of the chick embryo. Biochim. Biophys. Acta, 225: 113 (1971).

23. Proverbio, F., Robinson, J. W. L., and Whittembruy, G. Sensitivities of $\left(\mathrm{Na}^{+}-\mathrm{K}^{+}\right)$-ATPase and $\mathrm{Na}^{+}$-extrusion mechanisms of ouabain and ethacrynic acid in the cortex of the guinea pig kidney. Biochim. Biophys. Acta, 211: 327 (1970).

24. Reiser, $S$, and Christiansen, P. A.: Intestinal transport of amino acids studied with L-valine. Amer. J. Physiol., 208: 914 (1965).

25. Reiser, S., and Christiansen, P. A.: Intestinal transport of valine as affected by ionic environment. Amer. J. Physiol., 212: 1297 (1967).

26. Reiser, S., Fitzgerald, J. F., and Christiansen, P. A.: Kinetics of the accelerated intestinal valine transport in two-day-old rats. Biochim. Biophys. Acta, 203: 351 (1970).

27. Reiser, S., and Christiansen, P. A.: The properties of the preferential uptake of L-leucine by isolated intestinal epithelial cells. Biochim. Biophys. Acta, 225: 123 (1971).

28. Rosenberg, L. E., Downing, S. J., and Segal, S.: Extracellular space estimation in rat kidney slices using $\mathrm{C}^{14}$ disaccharides and phlorizin. Amer. J. Physiol., 202: 800 (1962).

29. Segal, S., Rea, C., and Smith, I.: Separate transport systems for sugars and amino acids in developing rat kidney cortex. Proc. Natl. Acad. Sci. U. S. A., 68: 372 (1971).

30. Schultz, S. G., and Curran, P. F.: Coupled transport of sodium and organic solutes. Physiol. Rev., 50: 637 (1970).

31. Spencer, R. P., and Samily, A. H.: Intestinal absorption of L-phenylalanine, in vitro. Amer. J. Physiol., 200: 501 (1961).

32. Warburg, O., and Christian, W.: Isolierung and Kristallisation des garungsferments enolase. Biochem. Z., 310: 384 (1942).

33. Webber, W. A.: Amino acid excretion patterns in developing rats. Can. J. Physiol. Pharmacol., 45: 867 (1967).

34. Webber, W. A., and Carins, J. A.: A comparison of the amino acid concentrating ability of the kidney cortex of newborn and mature rats. Can. J. Physiol. Pharmacol., 46: 165 (1968).

35. Webber, W. A.: A comparison of the effux rates of AlB from kidney cortex slices of mature and newborn rats. Can. J. Physiol. Pharmacol., 46: 765 (1968).

36. Wilson, T. H., and Wiseman, G.: The use of sacs of inverted small intestine for the study of the transference of substances from the mucosal to the serosal surfaces. J. Physiol. (London), 123: 116 (1954).

37. Wilson, T. H and Lin, E. C. C.: Active transport by intestines of fetal and newborn rabbits. Amer. J. Physiol., 199: 1030 (1960).

38. Tri-Carb, Packard Instrument, Downers Grove, Ill.

39. Amersham/Searle Corporation, Des Plaines, Ill.

40. New England Nuclear Corporation, Boston, Mass

41. West Point, Pa.

42. St Louis, Mo.

43. The authors are deeply indebted to Mr. William Gonzalez-Cruz for his technical assistance.

44. Supported by Riley Memorial Association Project no. 73-8.

45. Requests for reprints should be addressed to: J. F. Fitzgerald, M. D., Department of Pediatrics, Section of Gastroenterology, Indiana University School of Medicine, 1100 W. Michigan St., Indianapolis, Ind. 46202 (USA).

46. Accepted for publication July 9, 1974.

\section{Corrigendum}

Aromatic Acids in Urine of Healthy Infants, Persistent Hyperphenylalaninemia, and Phenylketonuria, before and after Phenylalanine Load

By S. Rampini et al.

Pediatric Research, Vol. 8, No. 7

p. 704--Under Subjects and Methods, weight of the premature infants at examination should have appeared as 1,990-2,500 $\mathrm{g}$ rather than 2,990-2,500 g. Furthermore, the healthy full term infants studied were seven.

p. 707--Under Aromatic Acids in Urine, the final sentence should have appeared as "The reported values for phenylacetic acid do not include phenylacetic acid originating from phenylacetylglutamine." 